\title{
THE IMPACT OF INSTITUTIONAL ENVIRONMENT ON RISK ASSESSMENT
}

\section{Steinhauser, D., Borovská, Z.}

Dušan Steinhauser / University of Economics in Bratislava, Faculty of Commerce, Department of International Trade, Dolnozemská cesta 1, Bratislava, Slovakia. Email: dusan.steinhauser@euba.sk

Zuzana Borovská / University of Economics in Bratislava, Faculty of Commerce, Department of International Trade, Dolnozemská cesta 1,Bratislava, Slovakia.Email: zuzana.borovska@euba.sk

\begin{abstract}
The purpose of this research is to investigate the relationship between the institutional environment of the studied countries and the Coface Country Risk Assessment. To meet this object, we used quantitative methods in the form of descriptive and regression analysis. The result was an evaluation of the actual Coface Country Risk Assessment and its value prediction for chosen countries. The authors quantified the impact of the institutional environment using The Heritage Index of Economic Freedom subindexes on the risk assessment indicator of the major private insurance company Coface, which is not so often used in the scientific sphere and is regularly updated. The results suggest a positive correlation between the Coface Country Risk Assessment and Government Integrity, Fiscal Health, Financial Freedom and Property Rights. Although Tax Burden is a statistically significant factor, its parameter was detected with an unexpected sign. For this reason, authors abstracted from it. Subindexes Government Spending, Business Freedom, Monetary Freedom, Trade Freedom, and Investment Freedom were statistically insignificant. Control variable Public Debt as a share of gross domestic product was insignificant as well.

Implications for Central European audience: The article applies the Coface Country Risk Assessment, which has so far been rarely used in the scientific literature. We present the current and predicted values of the Central European Countries, but also the countries interesting from their point of view due to trade and investment opportunities. Many countries, including those in Central Europe, show differences between actual and predicted values.
\end{abstract}

Keywords: Coface Country Risk Assessment; institutional environment; economic freedom JEL Classification: C52, E02, G22, O50

\section{Introduction}

Due to the constantly changing conditions in the world economy, the riskiness of countries in the international environment is rapidly shifting. The authors consider the institutional environment to be a factor influencing the degree of uncertainty in individual economies. In order to deepen the researched issue of the institutional environment and its impact on risk assessment, the authors decided to examine the degree of influence of the institutional environment on risk assessment. Coface Country Risk Assessment, specifically its assigned 
assessment to countries, helps other economies, businesses and the general public to expand their knowledge of countries' risks and ultimately determine their attitude towards them. The topic of the country's institutional environment and its impact on the outcome of the risk assessment is very important for the authors. Countries' knowledge of specific areas of the institutional environment by which they reduce or increase their ratings should be greatly needed. The authors examine the selected issue through regression analysis and consider the individual sub-indices of The Heritage's Index of Economic Freedom as indicators of the institutional environment, and Coface Country Risk Assessment is considered an indicator of risk assessment. Theoretically, we come from a new institutional economic theory. Among the leading representatives of this school of economics is Williamson (1990), who presented the economic system in its current real form, in which there is insufficient information, the possibility of opportunism and in which the so-called specific asset, such as a machine tailored to a specific customer. In such a world, there is natural risk exposure. It is necessary to create the so-called governance structures that generate transaction costs. For this reason, we have adopted the nomenclature for the purposes of this article and will use the term institutional environment.

A number of relevant studies confirm the importance of our chosen issue. The interdisciplinarity of risk assessment has been proven by Cesarini et al. (2009), who addressed this issue through research into human beings and their relationship to risk assessment and risk-taking. Their article is proof of the importance of risk assessment as an elementary indicator of several scientific disciplines. This article analyses the Coface Country Risk Assessment, which has already been affected by the manifestation of the crisis associated with the spread of Covid-19, which has affected both the supply and demand side, among other things, by increasing uncertainty (Baldwin \& Weder di Mauro, 2020).

\section{Literature review}

\subsection{General literature overview on institutional environment and risk assessment}

Given the meaning of the term institutional environment, Swaminathan and Wade $(2016$, p. 1) offered its definition: 'The institutional environment consists of normative and regulatory pressures exerted on organisations by the state or society and the professions. These pressures can be coercive and direct and enforced through mechanisms such as courts and regulations.' In connection with the economic science discipline, Douglass C. North and other new institutionalist recognised the importance of the institutional environment. According to North (1971), economists have misdirected their efforts in their search for the explanation of economic growth. His research points out that the answer on how to reach economic growth does not follow line in models of capital formation or other strategic variables but in the characteristics of the basic institutional environment and the degree to which these basic ground rules are enforced (North, 1971). Acemoglu et al. (2001) and North and Thomas (1973) also argue that countries with superior institutions which respect property rights will have better long-term outcomes in the form of higher productivity and economic growth. The new institutional economic theory deals precisely with the institutions, which it distinguishes into formal and informal. Formal institutions are mostly laws, regulations by the government or other authorities, and informal institutions represent a culture (Mlčoch, 2005). 
The importance of risks and risk assessment in microeconomic and macroeconomic processes is emphasised by many authors. According to Aven (2012), studying the concept of risk perspective is important for risk assessment, risk management and risk communication, as it could provide a strengthening of the understanding of these fields. In the case of the country risk assessment, Hoti and McAleer (2004) have found that country risk has become a topic of major concern for the international community. Their research indicated that 'risk rating agencies employ different methods to determine country risk ratings, combining a range of qualitative and quantitative information regarding alternative measures of economic, financial and political risk into associated composite risk ratings' (Hoti \& McAleer, 2004, p. 1). The international financial and business community began to address the issue of country risk assessment, especially in the period of increasing international debt of less developed countries in the 1970s and early 1980s (Cosset \& Roy, 1991). The fall of communism and the financial reforms of the countries significantly affected the volume of external financial capital flowing into emerging markets of Eastern Europe, Latin America, Asia, and Africa (Ramcharran, 1999). Hayes (1998) sees the globalisation of world trade and the opening of capital markets as reasons for financial crises that may threaten the international financial sector. According to Hoti and McAleer (2004), there are three major components of country risk: economic, financial, and political. While considering the international business environment, Overholt (1982) argues that international business scenarios are generally political-economic as businesses and individuals are interested in the economic consequences of political decisions.

The engaging thing about the presented article is that it builds on the creative history of our university department. When compiling the literature review and literature search, we found an article from 1995 by the author Michník (1995), who focused on the role of Coface in information networks through the analysis of the roles of specialised institutions in the business information system. Coface is the world's largest credit insurance company based in Paris, with traditionally good relations with the countries of Central and Eastern Europe. His research also covers commercial and political risks. He also stated that the commercial risks include documented and presumed insolvency of the debtor to meet obligations arising from the insured contract (Michník, 1995). Insured political risks include risks that do not arise from the economic or financial situation of the debtor, but from political and economic events and measures in the country of its registered office and from the point of view of the debtor they have the nature of force majeure (Michník, 1995). According to him, business information is the basis of successful business activity and emphasises that it is a prerequisite for minimising commercial and political risks.

Muir (2017) identified the importance of knowing the relationship between risk assessment and the institutional environment of the financial sector in times of crisis, whose results suggest that the health of the financial sector is irreplaceable in the risk management process. His study is also applicable to the situation since 2020 when the emphasis in the crisis of the pandemic is on the health of the financial sector as a prerequisite for successful management of commercial and political risks. Blau (2017) addressed the issue of the relationship between economic freedom and financial markets. His results suggest that countries with a higher level of economic freedom experience lower probabilities of market crashes and more positive skewness in asset returns. 'Components of economic freedom that contribute most to the reduction in crash risk is the level of free trade and, to some extent, the strength of property-right protection' (Blau, 2017, p. 22). Hassan et al. (2019) and Glova et al. (2020) 
focused on measuring political risks and their effect. Using a panel regression of the significance of the influence of economic and political factors on the riskiness of selected EU countries, Glova et al. (2020) defined the factors that most influence the country risk assessment are GDP p.c., inflation, unemployment, gross government debt, current account balance, international investment position and political control index of corruption and the rule of law.

\subsection{Particular literature overview on the risk assessment of Central European countries and Iran}

In her research, lloie (2015) focused on the countries of Central and Eastern Europe, in which she analysed the links and relationships between foreign direct investment, the Corruption Index (CPI) and Coface Country Risk Assessment, which is also a theoretical basis for orientation of our research. The analysis of territorial attractiveness and its determinants in terms of business opportunities was addressed by the authors Zykiene et al. (2020) and Brown et al. (2015), who examined the measurement and analysis of country risk itself.

Many authors address the risk assessment of the Iranian economy. Among them, Khadduri (1953) examines the role of the military in the politics of the Middle East, where he explains the role of the military in governing Iran in terms of its historical facts, influencing the perception of Iran's international position. The influence of the armed forces in Iran and Arab countries is also addressed in the research of Barany (2011). Rabi and Ter-Oganov (2012) underwent a detailed analysis of the Iranian army as an important factor of Iranian political stability, where they evaluated the position and structure of the army in the Iranian economy over time. Amuzegar (1999) also analyses the risk assessment of the Iranian economy, concluding that, given the past situation in the Iranian political environment, the struggle for freedom, human rights and democracy in Iran has not ended. Amuzegar's claim is also correlated with the current tense political situation affecting not only Iran's internal environment but also Iran's international position in the world economy, which is undermining its political stability in 2020.

\section{Methodology}

\subsection{Risk assessment methodology by Coface and Index of Economic Freedom methodology by The Heritage}

Coface country risk analysis is available for 160 countries around the world, whose assessments are based on macroeconomic, financial, and political data, which are regularly updated. Data provide an estimate of the average credit risk for businesses operating in the country. The overall risk is a combination of business-specific and country-specific factors in which the business operates. Coface's analysis uses an eight-step assessment in ascending order: A1, A2, A3, A4, B, C, D and E (Coface, 2020d).

Index of Economic freedom is annually published by The Heritage Foundation. The Index covers 12 freedoms in 184 countries. According to the Heritage Foundation (2021), the Index of Economic Freedom documents the positive relationship between economic freedom and a variety of positive social and economic goals. The Heritage Foundation measures economic freedom based on 12 quantitative and qualitative factors, divided into four broad categories of economic freedom: Rule of Law (property rights, government integrity, judicial effectiveness), Government Size (government spending, tax burden, fiscal health), 
Regulatory Efficiency (business freedom, labour freedom, monetary freedom) and Open markets (trade freedom, investment freedom, financial freedom). Each of the 12 economic freedoms within those categories is graded on a scale of 0 to 100. A country's overall score is derived by averaging these twelve economic freedoms, with equal weight being given to each (The Heritage Foundation, 2021a).

\subsection{General methodology}

The main object of this paper is to investigate the relationship between the institutional environment of the studied countries and the Coface Country Risk Assessment. To meet this object, we used quantitative methods in the form of descriptive and regression analysis of cross-sectional data. The result was an evaluation of the actual Coface country risk assessment and its value prediction for chosen countries. Data were acquired from the Coface database and The Heritage Foundation database (Table 1). The Coface Country Risk Assessment referred to the eight-digit range from $A 1$ to $E$. We had to encode a scale from 1 (best rating $A 1$ ) to 8 (the worst rating of $E$ ).

Table 1 | Description of variables (cross-sectional dataset)

\begin{tabular}{|c|c|}
\hline Variable & Description \\
\hline Coface_Risk_A_2020 & $\begin{array}{l}\text { Dependent variable Coface Country Risk Assessment, Business } \\
\text { Defaulting Risk from September } 2020\end{array}$ \\
\hline PR_2020 & Independent variable Property Rights from report 2020 \\
\hline JE_2020 & Independent variable Judicial Effectiveness from report 2020 \\
\hline GI_2020 & Independent variable Government Integrity from report 2020 \\
\hline TB_2020 & Independent variable Tax Burden from report 2020 \\
\hline GS_2020 & Independent variable Government Spending from report 2020 \\
\hline FH_2020 & Independent variable Fiscal Health from report 2020 \\
\hline BF_2020 & Independent variable Business Freedom from report 2020 \\
\hline LF_2020 & Independent variable Labour Freedom from report 2020 \\
\hline MF_2020 & Independent variable Monetary Freedom from report 2020 \\
\hline TF_2020 & Independent variable Trade Freedom from report 2020 \\
\hline IF_2020 & Independent variable Investment Freedom from report 2020 \\
\hline FF_2020 & Independent variable Financial Freedom from report 2020 \\
\hline GDP_pc_2020 & $\begin{array}{l}\text { Control variable Gross Domestic Product per Capita (PPP) from report } \\
2020\end{array}$ \\
\hline PD_GDP_2020 & Control variable Public Debt (\% of GDP) from report 2020 \\
\hline
\end{tabular}

Source: authors' own processing based on Coface (2020a), and The Heritage Foundation (2020). 
The descriptive statistics of the database can be found in Table 2. The quantitative analysis is significantly influenced by the number of observations marked with the letter ' $\mathrm{N}$ ', which in our case represented the number of examined countries. Another important characteristic is the value of mean and especially median. Median was used to model the hypothetical country. From other characteristics, we can determine standard deviation (St. Dev.), kurtosis (Kurt.), skewness (Skew.), minimum (Min.), and maximum (Max.). Interestingly, the skewness indicator is mostly negative in the case of the risk assessment and the institutional environment. Negative skewness means left-sided asymmetrical distribution. This indicates that there are more countries with higher values of variables than the average (Pacáková et al., 2009). Respecting the transformation of the Coface rating variable ( 1 = best rating; $8=$ the worst rating), there are more countries with a worse risk assessment than the average. We consider Property Rights, Judicial Effectiveness and Government Integrity to be crucial in setting up the institutional environment, and in this case, there are more countries with less than average value.

Table 2 | Descriptive statistics

\begin{tabular}{|c|c|c|c|c|c|c|c|c|}
\hline Variable & Mean & Median & St. Dev. & Kurt. & Skew. & Min. & Max. & $\mathbf{N}$ \\
\hline Coface_Risk_A_2020 & 5.4 & 6.0 & 1.7 & -0.8 & -0.4 & 2.0 & 8.0 & 158 \\
\hline PR_2020 & 57.3 & 57.1 & 19.2 & -0.6 & 0.1 & 10.1 & 96.8 & 158 \\
\hline JE_2020 & 45.6 & 43.5 & 19.4 & -0.5 & 0.3 & 5.0 & 92.9 & 158 \\
\hline GI_2020 & 45.2 & 38.8 & 22.1 & -0.3 & 0.8 & 13.1 & 96.1 & 158 \\
\hline TB_2020 & 76.9 & 78.5 & 13.6 & 5.9 & -1.5 & 0.0 & 99.8 & 154 \\
\hline GS_2020 & 66.4 & 71.0 & 22.2 & 0.9 & -1.1 & 0.0 & 96.5 & 157 \\
\hline FH_2020 & 68.0 & 80.0 & 31.2 & -0.5 & -0.9 & 0.0 & 99.9 & 156 \\
\hline BF_2020 & 63.9 & 64.4 & 16.0 & 1.0 & -0.6 & 5.0 & 96.2 & 158 \\
\hline LF_2020 & 58.3 & 58.6 & 14.6 & 0.8 & -0.3 & 5.0 & 90.9 & 158 \\
\hline MF_2020 & 74.2 & 76.6 & 11.5 & 20.8 & -3.8 & 0.0 & 87.0 & 158 \\
\hline TF_2020 & 74.9 & 78.0 & 12.3 & 7.5 & -1.8 & 0.0 & 95.0 & 156 \\
\hline IF_2020 & 58.0 & 60.0 & 22.8 & 0.1 & -0.8 & 0.0 & 95.0 & 157 \\
\hline FF_2020 & 50.5 & 50.0 & 19.6 & -0.5 & -0.3 & 0.0 & 90.0 & 154 \\
\hline GDP_pc_2020 & 22228.3 & 13987.1 & 22658.9 & 4.0 & 1.8 & 711.9 & 130475.1 & 158 \\
\hline PD_GDP_2020 & 58.4 & 51.0 & 35.5 & 4.9 & 1.7 & 0.1 & 237.1 & 157 \\
\hline
\end{tabular}

Source: authors' own processing based on Coface (2020a), and The Heritage Foundation (2020). 
The variables Gross Domestic Product (GDP) per capita and Public Debt as a Share of GDP represent control variables. We analysed both control variables in logarithmic form, i.e. and clarified their regression coefficients as a nominal change induced by the percentual change.

Due to the selection of a suitable correlation coefficient, which is recommended before compiling the regression analysis, we will check the normal distribution of variables. The correlation analysis and normality tests were assembled using the PAST software (Hammer et al., 2001). Table 3 shows that all variables (except LF_2020) are not normally distributed. For this reason, we will use correlation analysis using Kendall's tau.

Table 3 | Tests of distribution normality

\begin{tabular}{llcccc}
\hline p(normal) & N & Shapiro-Wilk & Anderson-Darling & Lilliefors & Jarque-Bera \\
\hline Coface_Risk_A_2020 & 158 & 0.00 & 0.00 & 0.00 & 0.02 \\
PR_2020 & 158 & 0.03 & 0.03 & 0.07 & 0.23 \\
JE_2020 & 158 & 0.01 & 0.00 & 0.05 & 0.08 \\
Gl_2020 & 158 & 0.00 & 0.00 & 0.00 & 0.00 \\
TB_2020 & 154 & 0.00 & 0.00 & 0.00 & 0.00 \\
GS_2020 & 157 & 0.00 & 0.00 & 0.00 & 0.00 \\
FH_2020 & 156 & 0.00 & 0.00 & 0.00 & 0.00 \\
BF_2020 & 158 & 0.00 & 0.05 & 0.14 & 0.00 \\
LF_2020 & 158 & 0.12 & 0.41 & 0.68 & 0.06 \\
MF_2020 & 158 & 0.00 & 0.00 & 0.00 & 0.00 \\
TF_2020 & 156 & 0.00 & 0.00 & 0.00 & 0.00 \\
IF_2020 & 157 & 0.00 & 0.00 & 0.00 & 0.00 \\
FF_2020 & 154 & 0.00 & 0.00 & 0.00 & 0.14 \\
I_GDP_pc_2020 & 158 & 0.00 & 0.00 & 0.02 & 0.04 \\
I_PD_GDP_2020 & 157 & 0.00 & 0.00 & 0.00 & 0.00 \\
\hline
\end{tabular}

Source: authors' own processing based on Coface (2020a), and The Heritage Foundation (2020).

Quantitative analysis was compiled and interpreted based on expert literature (Hanák, 2016; Lukáčik et al., 2011; Pacáková et al., 2009). Collinearity was detected by Adkins et al. (2015). Analysis was compiled using Microsoft Excel and software GRETL (Cottrell \& Lucchetti, 2021), while the regression equation had the following form:

$y_{i}=\beta_{0}+\beta_{1} x_{i 1}+\beta_{2} x_{i 2}+\cdots+\beta_{k} x_{i k}+u$,

whereby $\beta_{0}$ represents a constant, parameters $\beta_{1}$ to $\beta_{\mathrm{k}}$ are estimations of independent variables, $y_{i}$ stand as a dependent variable, $x_{i}$ and $x_{i k}$ are individual independent variables, and $u$ signifies an additive component (Lukáčik et al., 2011). Using the method of quantitative analysis allowed us to test the following hypotheses:

H1: As the value of The Heritage Foundation Index of Economic Freedom subindexes increases, we expect a quality improvement in the Coface Risk Assessment, i.e. we expect a decrease in the value of the dependent variable and a negative sign of estimate parameter. 
H2: With an increase in the natural logarithm of Gross domestic product per capita, we expect a quality improvement in Coface Risk Assessment, i.e. we expect a decrease in the value of the dependent variable and a negative sign of estimate parameter.

It is true that the Coface Country Risk Assessment was already influenced by the effect of the Covid-19 crisis, and The Heritage Foundation Index of Economic Freedom is still assessing the pre-crisis situation. Our specification reveals the interpretive space of the analysis. From our point of view, the pre-crisis state of the institutional environment significantly determines the ability to manage the effects of the Covid-19 crisis and highlights potential hidden shortcomings in the quality of the institutional environment of countries that already existed in the countries. The pre-crisis period can be evaluated based on the study by Čukanová and Steinhauser (2018), which contains a regression analysis of a similar specification from 2017. The authors, in contrast to our study, proved the influence of the Property Rights variable (reg. coeff. -0.024), Government Integrity (reg. coeff. -0.025), Financial Freedom (reg. coeff. -0.014) and the natural logarithm of Gross domestic product p. c. (reg. coeff. -0.324). Business Freedom subindex was estimated with an unexpected positive sign.

\section{Results and Discussion}

\subsection{Country Risk Assessment}

Table 4 contains a correlation analysis that demonstrated the moderate link between Coface Country Risk Assessment and Protection of Property Rights, Judicial Effectiveness, Government Integrity, Business Freedom, Monetary Freedom, Trade Freedom, Investment Freedom and Financial Freedom. All these coefficients have the expected negative sign. The weakness of correlation analysis is represented by the fact that it examines only isolated pairs of occurrences. For this reason, we will assess our hypotheses in the light of regression analysis.

Table 4 | Correlation analysis using Kendall's tau

\begin{tabular}{lcc}
\hline & Coface_Risk_A_2020 & I_GDP_pc_2020 \\
\hline PR_2020 & -0.70 & 0.61 \\
JE_2020 & -0.61 & 0.49 \\
GI_2020 & -0.65 & 0.65 \\
TB_2020 & 0.19 & -0.06 \\
GS_2020 & 0.24 & -0.36 \\
FH_2020 & -0.34 & 0.24 \\
BF_2020 & -0.55 & 0.52 \\
LF_2020 & -0.28 & 0.26 \\
MF_2020 & -0.40 & 0.33 \\
TF_2020 & -0.50 & 0.52 \\
IF_2020 & -0.55 & 0.43 \\
FF_2020 & -0.60 & 0.52 \\
I_GDP_pc_2020 & -0.57 & \\
I_PD_GDP_2020 & 0.05 & -0.03 \\
\hline
\end{tabular}

Source: authors' own processing based on Coface (2020a), and The Heritage Foundation (2020).

During the research, we have compiled a multi regression analysis 1 concerning the relationship between the Coface Country Risk Assessment published on 8 October 2020 and 
the Index of Economic Freedom subindexes from the 2020 report. After omitting significant estimations, we compiled multi regression analysis 2 (Table 5). In analysis 1, we used the 'Variance Inflation Factors' method to identify problems with collinearity in the case of the Property Rights variable (value $11.11>10$ ), which we then omitted from the model and created a separate model 3 . All three models do not show significant statistical errors. Using White's test, we exclude the heteroskedasticity error, and the residues had a normal distribution in both cases. For this reason, we can proceed to the interpretation of statistically significant variables from models 2 and 3 .

Table 5 | Regression analysis, OLS-estimates, Dependent variable: Coface_Risk_A_2020

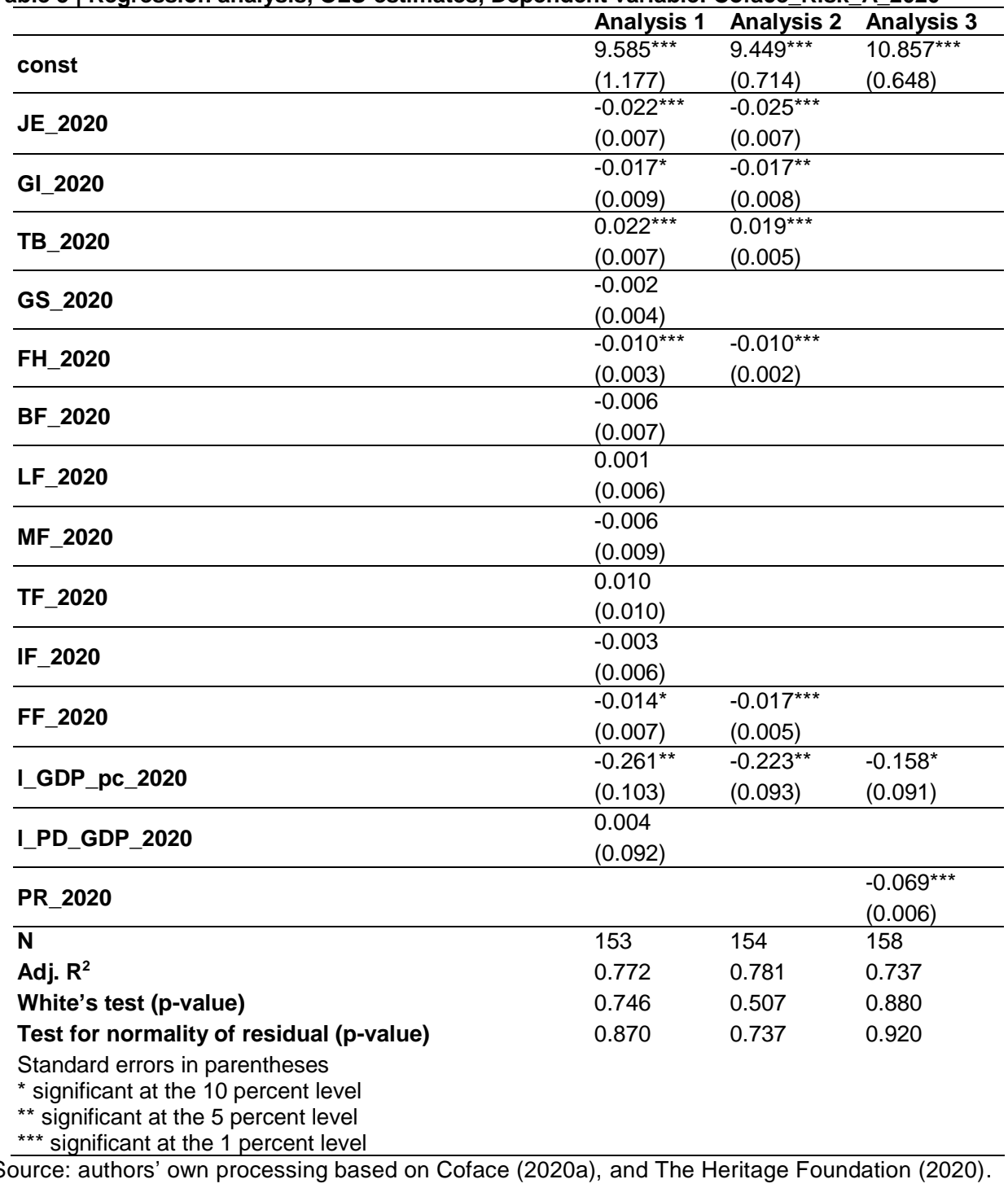


The number of asterisks is associated with the value of the probability of rejection of the null hypothesis $\left(\mathrm{H}_{0}\right)$ about the insignificance of the estimate of variables, while the hypothesis is tested at the significance level of 0.05 (5\% level). Statistical hypothesis $\mathrm{H}_{0}$ can be rejected for all variables in analyses 2 and 3 (except the control variable in analysis 3 ). All variables had the expected negative sign, apart from the Tax Burden variable. With the qualitative improvement of this variable, we expect a deterioration of the risk exposure. In general, we can say that a change in the value of individual variables by about 50 points ceteris paribus will cause a change in the Coface Country Risk Assessment by 1 degree. It is clear from this fact that a change in risk assessment requires a combination of several factors, which can be described as an institutional environment. The statistical significance of all variables from model 2 allows us to model the predicted value of the risk assessment of a hypothetical country, which would reach the median value of independent variables in table 4 . The hypothetical country would achieve risk assessment at approximately B level (Table 6).

Table 6 | Median country and prediction

\begin{tabular}{lcc}
\hline Variable & Median of actual values & Predicted Risk Assessment \\
\hline Judicial Effectiveness & 43.5 & \\
Government Integrity & 38.8 & \\
Tax Burden & 78.5 & $5.43=\sim 5(\mathrm{~B})$ \\
Fiscal Health & 80.0 & \\
Financial Freedom & 50.0 & \\
Gross domestic product p. c. & $\ln (13987.1)$ &
\end{tabular}

Source: authors' own processing based on Coface (2020a) and The Heritage Foundation (2020).

Regarding the problem of collinearity, we used the 'Variance Inflation Factors (VIR)' method (Adkins et al., 2015). We mentioned that we tried to solve this problem by allocating the Property Rights variable to a separate model in which the VIR no longer detects the problem with collinearity (VIR: $2.393<10)$. However, analysis 2 contains a relatively high VIR value of the Government Integrity variable (VIR: $8.056<10)$. This value does not reach the threshold, but it is a reason for suspicion. For the robustness of our estimates, we present pairwise regression coefficients for each variable parameter estimate. For pairwise regression, there can be no problem with collinearity because the specification of the equation contains only one independent variable (Table 7).

Table 7 | Pairwise regression analysis (HC - heteroskedasticity corrected estimation) compared with Analysis 2

\begin{tabular}{lcc}
\hline Variable & Pairwise reg. an. / const / R-sq. / est. & Analysis 2 (Table 5) \\
\hline Judicial Effectiveness & $-0.070^{* * *} / 8.581^{* * *} / 0.62 / \mathrm{OLS}$ & $-0.025^{* * *}$ \\
Government Integrity & $-0.065^{* * *} / 8.355^{* * *} / 0.81 / \mathrm{HC}$ & $-0.017^{* *}$ \\
Tax Burden & $0.034^{* * *} / 2.756^{* * *} / 0.06 / \mathrm{HC}$ & $0.019^{* * *}$ \\
Fiscal Health & $-0.025^{* * *} / 7.094^{* * *} / 0.28 / \mathrm{HC}$ & $-0.010^{* * *}$ \\
Financial Freedom & $-0.058^{* * *} / 8.237^{* * *} / 0.59 / \mathrm{HC}$ & $-0.017^{* * *}$ \\
I_GDP_pc_2020 & $-1.005^{* * *} / 14.889^{* * *} / 0.49 / \mathrm{OLS}$ & $-0.223^{* *}$ \\
\hline
\end{tabular}

Source: authors' own processing based on Coface (2020a), and The Heritage Foundation (2020).

It is not unexpected that the pairwise regression analysis parameter estimates are higher than multiple analyses. In combination with analysis 3 , we can confirm that the most important 
factors from our analysis that affect risk assessment are the protection of Property Rights, Judicial Effectiveness, Financial Freedom, and control variable natural logarithm from Gross domestic product per capita. This result is consistent with correlation analysis. Regression analysis 2 (Table 5) can reveal other important facts if we observe the residues values (Figure 1). The largest negative deviations of the actual and predicted values are achieved by Armenia (actual value D, predicted risk assessment B), Iran (actual value E, predicted C), Argentina (actual value D, predicted B). Malta (actual value A2, predicted A4), Senegal (actual value A4, predicted value C), Bolivia (actual value $C$, predicted value between D and E) achieve a negative deviation. Other notable deviations include Japan (actual value A2, predicted value A3-A4), Spain (actual value A3, predicted value A4), United Kingdom (actual value A4, predicted value A2-A3), Turkey (actual value $C$, predicted risk Assessment value A4-B) and Ukraine (actual value D, predicted value C). On the other hand, Romania, for example, achieves the same value of actual and predicted risk assessment.

During October 2020, the assessment of some countries deteriorated, which we can use to check the predictive capability of our analysis. From the Coface Country Risk Assessment Map (Coface, 2020b), we find that the rating for Belize has deteriorated (the latest October 2020 Coface Country Risk Assessment D, the actual database for our paper Coface_Risk_A_2020 C, predicted value of risk assessment from actual values C), for Senegal (October 2020 Coface Country Risk Assessment B, Coface_Risk_A_2020 A4, predicted risk assessment C), Niger (October 2020 Coface risk assessment D, Coface_Risk_A_2020 C, predicted risk assessment D), India (October 2020 Coface Country Risk Assessment C, Coface_Risk_A_2020 B, predicted risk assessment C), Hong Kong (October 2020 Coface Country Risk Assessment A4, Coface_Risk_A_2020 A3, predicted risk assessment $\mathrm{A} 3)$.

As we have mentioned, there are overvalued and undervalued countries. Malta and Senegal are examples of two overvalued countries. By contrast, Armenia and Iran appear to be underestimated. According to Coface, Malta's weaknesses include dependence on tourism, financial flows from the gambling business, crypto-currencies or offshore, high levels of corruption and nepotism, problems with infrastructure, or a skilled workforce. These determinants reduce the quality of the institutional environment and could have distorted the higher value of residuals. Strengths include the geographical location, which allows the country to act as a transport hub for maritime transport, the low level of taxation, the Englishspeaking workforce, and the fact that Malta's creditors are also residents (Coface, 2021b). Similarly, Senegal, which is dependent on commodity prices, especially food prices, has poorly built infrastructure. Half the population lives in poverty and is heavily indebted. In terms of imports, Senegal is dependent on energy imports. By contrast, Senegal is relatively politically stable with an improving business environment but with persistent corruption. Senegal also owns oil and gas reserves as well as several other mining commodities (Coface, 2021c). Apart from the military conflict with Azerbaijan, one of Armenia's weaknesses is its dependence on primary raw materials (e.g. zinc, gold, copper), but its occurrence is one of the country's strengths. Other weaknesses mentioned by Coface include the problem of poverty and unemployment, dependence on the Russian Federation in trade, investment, and remittances. Armenia has insufficiently built infrastructure and is partially isolated for geopolitical reasons. On the other hand, Coface states that Armenia is in favour of reforms or receiving international aid (Coface, 2021a). Iran is a country that is a long-term interest of 
our workplace, is a member of the Belt and Road initiative and for this reason, we can provide a closer institutional analysis of it in a separate subchapter.

Figure 1 | Actual and predicted values - analysis 2

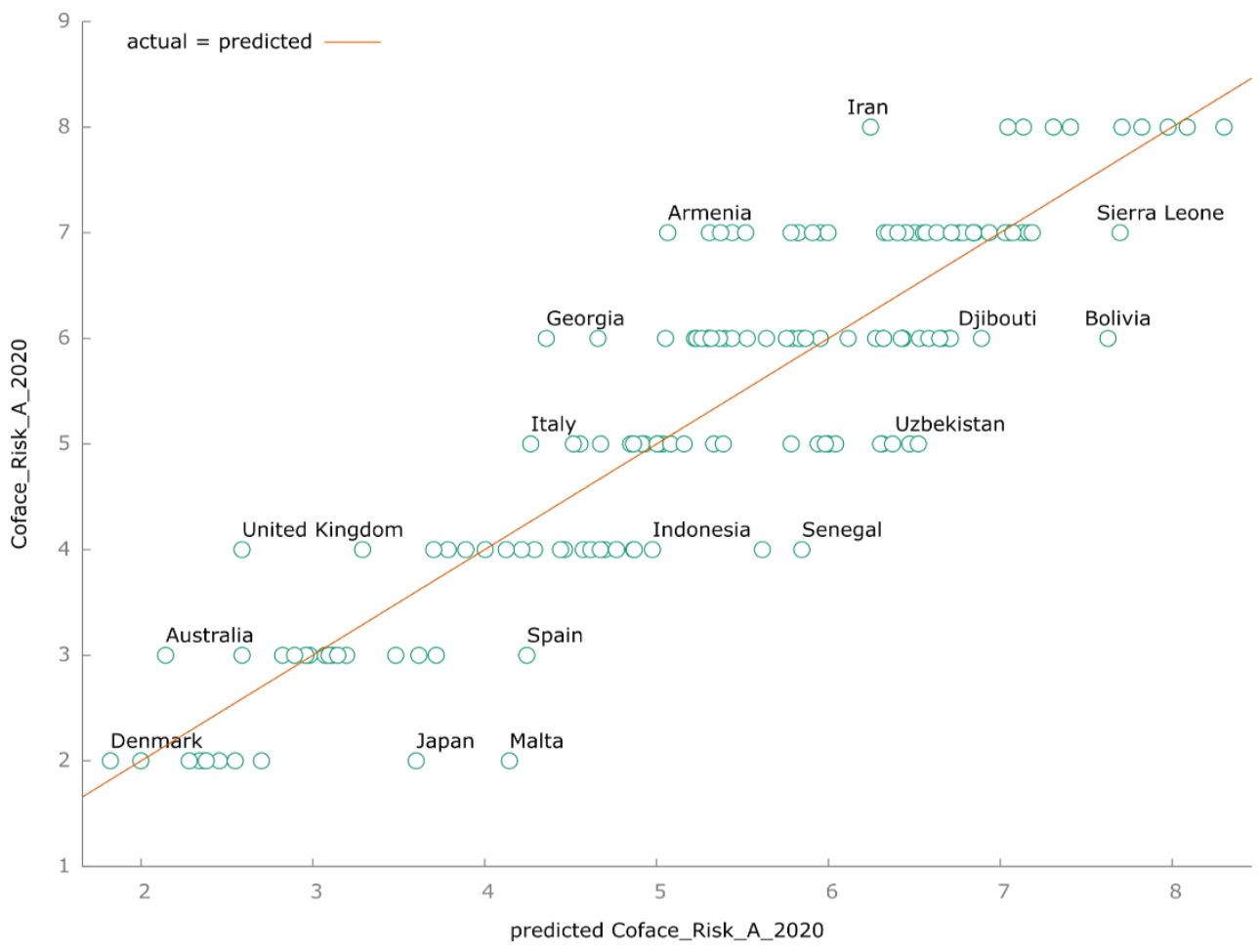

Source: authors' own processing based on Coface (2020a) and The Heritage Foundation (2020).

\subsection{Central European region Risk Assessment}

From the Central European region, we have focused mainly on Germany, Czech Republic, Slovakia, Poland, and Hungary (Table 8). Germany, Czech Republic, and Poland achieve the same predicted and actual values. In the case of Hungary and Slovakia, our prediction estimates a one-degree deterioration.

In the case of Central European countries, we decided to present a summary of the advantages and disadvantages for the Czech Republic, Hungary, Poland, and Slovakia, which arise in the context of the researched issues for these economies (Table 9). From all the mentioned countries, only the Czech Republic has mostly free economic freedom status. Hungary, Poland, and Slovakia are ranked as countries with moderately free economic status (The Heritage Foundation, 2021b). 
Table 8 | Actual and predicted values - selected countries

\begin{tabular}{|c|c|c|c|c|c|}
\hline Variable & Germany & Czech Republic & Hungary & Poland & Slovakia \\
\hline Coface_Risk_A_2020 & $\mathrm{A} 3$ & $\mathrm{~A} 4$ & $\mathrm{~A} 4$ & $\mathrm{~A} 4$ & $\mathrm{~A} 4$ \\
\hline Predicted Risk_A_2020 & A3 $(2,8)$ & A4 $(4,0)$ & $\mathrm{B}(4,7)$ & A4 $(4,3)$ & $\mathrm{B}(4,6)$ \\
\hline GDP_pc_2020 & 52558.69 & 37370.97 & 31902.67 & 31938.66 & 35129.79 \\
\hline PD_GDP_2020 & 59.75 & 32.96 & 69.39 & 48.36 & 48.85 \\
\hline PR_2020 & 80.50 & 76.80 & 64.80 & 63.10 & 73.10 \\
\hline JE_2020 & 74.30 & 49.90 & 45.70 & 42.80 & 41.70 \\
\hline GI_2020 & 82.80 & 64.20 & 47.50 & 64.60 & 49.70 \\
\hline TB_2020 & 60.90 & 82.00 & 79.90 & 74.70 & 78.50 \\
\hline GS_2020 & 42.20 & 52.70 & 34.50 & 48.80 & 50.20 \\
\hline FH_2020 & 92.90 & 97.80 & 83.60 & 92.20 & 92.60 \\
\hline BF_2020 & 82.80 & 69.70 & 60.20 & 62.60 & 55.30 \\
\hline LF_2020 & 53.00 & 77.60 & 64.60 & 62.00 & 52.60 \\
\hline MF_2020 & 76.70 & 80.80 & 79.90 & 82.00 & 75.90 \\
\hline TF_2020 & 86.40 & 86.40 & 86.40 & 86.40 & 86.40 \\
\hline IF_2020 & 80.00 & 80.00 & 80.00 & 80.00 & 75.00 \\
\hline FF_2020 & 70.00 & 80.00 & 70.00 & 70.00 & 70.00 \\
\hline
\end{tabular}

Source: authors' own processing based on Coface (2020a), and The Heritage Foundation (2020).

Table 9 | Advantages and disadvantages of the Central European countries in the context of Economic Freedom Index

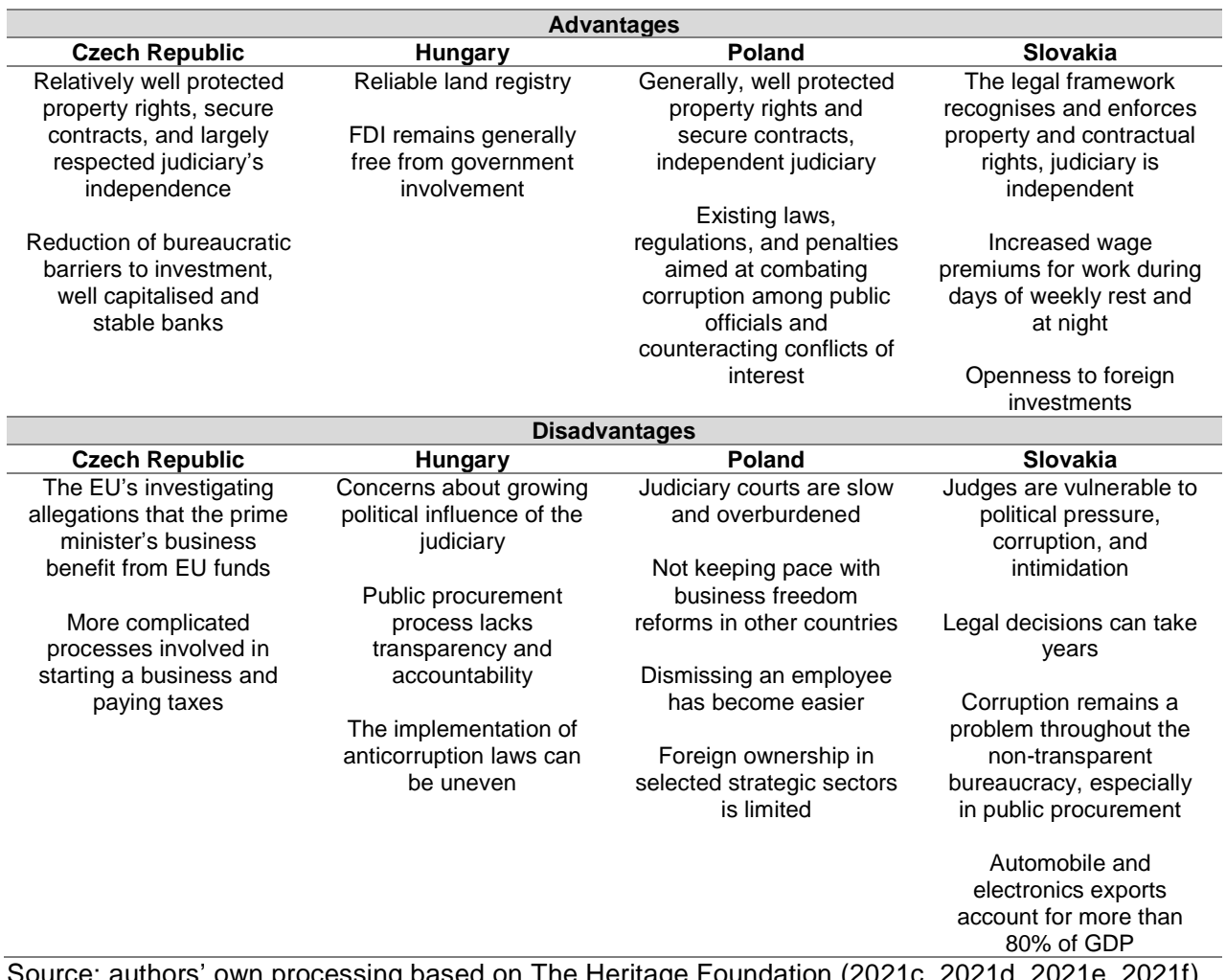

Source: authors' own processing based on The Heritage Foundation (2021c, 2021d, 2021e, 2021f). 
Of these countries (table 9), we observe the highest unemployment in Slovakia $(5.6 \%$ in 2019), while Poland (3.5\%) and Hungary (3.4\%) showed lower unemployment in 2019. The Czech Republic has the lowest unemployment, at only $1.9 \%$ in 2019 . Of the abovementioned Central European countries, Hungary has the highest public debt $(66.3 \%$ of GDP). The public debt of Slovakia represents $48.2 \%$ of GDP and Poland $46.7 \%$ of GDP. Of these countries, The Czech Republic has the lowest public debt, amounting to $30.8 \%$ of GDP in 2019. The highest inflow of FDI was recorded in Poland (\$13.2 billion in 2019), followed by the Czech Republic ( $\$ 7.6$ billion), Hungary ( $\$ 5.2$ billion) and Slovakia (\$2.4 billion) (The Heritage Foundation, 2021c, 2021d, 2021e, 2021f).

\subsection{Iranian Country Risk Assessment}

While evaluating our results, we were surprised by the high level of undervaluation of Iran. Using Iran as an example, we decided to point out the Iranian institutional environment, as, among other things, the country represents a potential trading partner for the Central European countries. As already mentioned, Iran has been assigned an E rating, which indicates extreme risk. Coface (2020c) predicts Iran's economic growth at $-0.8 \%$ with a yearon-year increase of $1.5 \%$. Within macroeconomic indicators, it also forecasts average inflation at $31 \%$ in 2020 , with a year-on-year decline of $4.7 \%$, a budget balance of $-5 \%$ of GDP, a balance of payments of $-3.4 \%$ and public debt of 28.8 with a year-on-year decrease of $1.9 \%$ (Coface, 2020c). The low assessment in the country risk assessment is mainly based on the pressure of US sanctions, which, in connection with the unilateral withdrawal of the USA from the nuclear agreement that took place in May 2018, negatively determine the economic condition of the Iranian economy. The unfavourable development of the Iranian economy is also affected by reduced oil exports and its low prices resulting from the slowdown in the global economy.

Coface (2020c) considers US sanctions to be a significant weakness in the Iranian economy. Iran's tense relations with the United States are justified by Iranian interventionism in the Middle East region, but especially by a possible threat to the development of a nuclear weapon. A possible secondary, in our view, the fundamental cause of American sanctions may be the problem of democracy and respect for human rights. Likewise, Iran's growing influence in the Middle East could pose a huge threat of a loss of US influence in the region. The problem of democracy in Iran is more than obvious. According to Gheissari and Nasr (2006), the people of Iran do not live in a democracy, but their policies are greatly influenced by its basic logic. Democracy in Iran was not the goal of the Islamic Revolution but the unintended consequence of its development. Nor was it an imported instrument, as an ideal form of policy from the West, but rather appeared to be a common phenomenon. Democratic thinking and political expectations still prevail in Iranian society and serve as the main impetus for the ongoing struggle for democratic change in the country. The challenge facing democratisation in developing countries is the issue of political reforms, which often do not work as society has not yet adopted democratic values and practices (Gheissari \& Nasr, 2006). Democratic politics cannot work where political culture has not adopted the values and practices of democracy and where people's attitudes toward authority do not reflect such values and commitments. In Iran, however, we are pursuing a democratic stance in society and not state reforms, in line with progress towards democracy. It is this development that distinguishes Iran from other countries in the Middle East. The Iranians are aware of the unfavourable situation and, to a certain extent, are expressing it. In 1999, the country's 
instability and dissatisfaction with students in Tehran reflected the Iranian government's undemocratic practices. In his publication, Amuzegar (1999) argued that, given the political environment at the time, it would be naive to assume that the struggle for freedom, human rights, and democracy in Iran had stopped. As none of the root causes of the initial protests - socio-cultural constraints and ongoing economic difficulties - were effectively addressed by the Iranian government, Amuzegar (1999) assumed that various factions would re-ignite and disrupt the country. However, the 1999 student revolt was not the first or last uprising against the Iranian regime's interference with the daily lives of the Iranian people. The current tense political situation, which affects not only Iran's internal environment but also Iran's overall international position in the world economy, correlates with Amuzegar's claim.

However, the Iranian political regime is very complex. According to Axworthy (2014), it has many shortcomings, but on the other hand, except for Israel, it is more friendly than other regimes in most countries in the Middle East. Despite repressive state measures, he argued that Iran was not one of the totalitarian countries typical of the former Soviet bloc countries during the Cold War. Axworthy (2014) points to the possibility of political transformation of Iran, the basis of which is conditioned mainly by social and political changes, education, and awareness of the Iranian population. Based on the results of the regression analysis, we state that despite the value of Coface Country Risk Assessment, which gave Iran an $E$ rating (extreme), our calculations assign Iran a $\mathrm{C}$ rating (high), i.e. better evaluation by two places, which can also be confirmed by the statement about a possible political transformation of Iran.

Our study also has an impact on the issue of the relationship between informal institutions and the macroeconomic environment. The institutional environment represents the synergy of formal and informal institutions, regulation, culture, but also customs. Most qualitative indicators are similarly assessed by formal and informal institutions. Corruption is one of the most important informal institutions having an impact on economies. The Heritage Index of Economic Freedom (The Heritage Foundation, 2021b) evaluates corruption within the Government Integrity sub-index. Kittová and Steinhauser (2017) confirmed the assumption that the institutional environment determines the macroeconomic environment of companies, but also vice versa. They illustrated this fact with the example of the issue of Corporate Governance. Other authors (Ba Trung \& Kaizoji, 2017; Munger, 2018; de Soto in Marquez, 1990) argue that in certain circumstances, in the event of the failure of formal institutions, informal institutions may take the initiative. $\mathrm{H}$. de Soto studied the role of informal housing, trade, and transportation in the Peruvian economy. Ba Trung and Kaizoji (2017) investigated the investment climate in Vietnam, and they claim: "Corruption acts as "speed money" to improve the efficacy of the provision of public services or provides leeway for entrepreneurs to bypass inefficient regulations. However, this circumstance is detrimental to the economy in the long run because it distorts the market and erodes the belief in and motivation for productive investments.' Our results also showed a positive impact on countries' risk assessments.

\section{Conclusion}

The presented article analyses the influence of the institutional environment quantified using the subindexes The Heritage Index of Economic Freedom on the Coface Country Risk Assessment. The Coface Country Risk Assessment indicator has so far only rarely been mentioned in the scientific literature, which we consider to be the advantage of this article. 
We applied multi regression analysis, using a cross-sectional sample analysis of 153-158 countries around the world from the year 2020 or from the 2020 report (depends on the specification of the regression analysis), allowing the estimation of significant parameters that affected the independent variable. Based on the results of the regression analysis, Hypothesis 1 was rejected because not all subindexes of The Heritage Index of Economic Freedom showed a significant impact on Coface risk assessment. There is a positive correlation between improving Coface risk assessment and improving Government Integrity, Fiscal Health, Financial Freedom and Property Rights. Although the Tax Burden is a statistically significant factor, its parameter was dramatic with an unexpected sign. For this reason, we abstract from its interpretation. Hypothesis 2 was confirmed because we have shown that as the natural logarithm of Gross domestic product per capita increases, Coface risk assessment improves. We state that the analysis provided us with sufficient evidence to confirm this hypothesis.

The time period could be a limitation of our research because the September 2020 Coface risk assessment reflects the manifestations of the crisis associated with the spread of Covid19 , but we tried to reduce and use this limitation by comparing the current period with the pre-crisis period and comparing the new Coface risk assessment, published in October 2020.

From the results of our analysis, we can make a recommendation to the decision-making sector to invest in improving the institutional environment, which in line with the new institutional economic theory will contribute to reducing macroeconomic transaction costs and thus to a more efficient economical process and ability to better withstand and overcome economic crises, which may also take the form of a pandemic.

\section{Acknowledgement}

This work was supported by the Ministry of Education, Family and Sports of the Slovak Republic VEGA (in the period 2020-2022) No. 1/0777/20: The Belt and Road initiative - an opportunity or a threat for the EU and Slovak export competitiveness?

\section{References}

Acemoglu, D., Johnson, S., \& Robinson, J. A. (2001). The colonial origins of comparative development: An empirical investigation. American Economic Review, 91(5), 1369-1401. https://doi.org/10.1257/aer.91.5.1369

Adkins, L., Waters, M., \& Hill, C. (2015). Collinearity Diagnostics in gretl. Economics Working Paper Series 1506, Oklahoma University. https://learneconometrics.com/pdf/Collin/collin_gretl.pdf

Amuzegar, J. (1999). Iran's future: Civil society or civil unrest? Middle East Policy, 7(1), 86-100.

Aven, T. (2012). The risk concept - Historical and recent development trends. Reliability Engineering \& System Safety, 99, 33-44. https://doi.org/10.1016/j.ress.2011.11.006

Axworthy, M. (2014). Dějiny Iránu. Nakladatelství Lidové noviny.

Ba Trung, N., \& Kaizoji, T. (2017). Investment climate and firm productivity: An application to Vietnamese manufacturing firms. Applied Economics, 49(44), 4394-4409. https://doi.org/10.1080/00036846.2017.1282148 
Baldwin, R., \& Weder di Mauro, B. (2020). Introduction. In R. Baldwin \& B. Weder di Mauro (Eds.), Mitigating the COVID economic crisis: Act fast and do whatever it takes (pp. 1-25). CEPR Press.

Barany, Z. (2011). The role of the military. Journal of Democracy, 22(4), 24-35, https://doi.org/10.1353/jod.2011.0069

Blau, B. M. (2017). Economic freedom and crashes in financial markets. Journal of International Financial Markets, Institutions and Money, 47, 33-46. https://doi.org/10.1016/j.intfin.2016.11.010

Brown, C. L., Cavusgil, S. T., \& Lord, A. W. (2015). Country-risk measurement and analysis: A new conceptualisation and managerial tool. International Business Review, 24(2), 246-265. https://doi.org/10.1016/j.ibusrev.2014.07.012

Cesarini, D., Dawes, C. T., Johannesson, M., Lichtenstein, P., \& Wallace, B. (2009). Genetic variation in preferences for giving and risk taking. Quarterly Journal of Economics, 124(2), 809-842. https://doi.org/10.1162/qjec.2009.124.2.809

Coface. (2020d). Economic studies and country risk. https://www.coface.com/Economic-Studies-andCountry-Risks

Coface. (2020a). Country risk assessment map - September 2020. https://www.coface.com/content/download/182477/3009902/file/COUNTRY_RISK_ASSESSM ENT_MAP-Q2-2020.pdf

Coface. (2020b). Country risk assessment map - October 2020. https://cofaceitfirst.com/resources/country-risk-assessment-map-october-2020

Coface. (2020c). Iran risk assessment. https://www.coface.com/Economic-Studies-and-CountryRisks/Iran-Islamic-Republic-of

Coface. (2021a). Economic studies and country risks (Armenia). https://www.coface.com/EconomicStudies-and-Country-Risks/Armenia

Coface. (2021b). Economic studies and country risks (Malta). https://www.coface.com/EconomicStudies-and-Country-Risks/Malta

Coface. (2021c). Economic studies and country risks (Senegal). https://www.coface.com/EconomicStudies-and-Country-Risks/Senegal

Cosset, J. C., \& Roy, J. (1991). The determinants of country risk ratings. Journal of International Business Studies, 22(1), 135-142. https://doi.org/10.1057/palgrave.jibs.8490296

Cottrell, A., \& Lucchetti, R. (2021). Gretl user's guide. http://gretl.sourceforge.net/gretl-help/gretlguide.pdf

Čukanová, M., \& Steinhauser, D. (2018). Transformation process and service sector in V4 countries. In A. Cierniak-Emerych, S. Dziuba, A. Pietroń-Pyszczek \& A. Bodak (Eds.), Enterprise and human resource management as areas of innovations (pp. 62-114). Oficyna Wydawnicza Stowarzyszenia Menedżerów Jakości i Produkcji.

Gheissari, A., \& Nasr, V. (2006). Democracy in Iran: History and the quest for liberty. Oxford University Press.

Glova, J., Bernatik, W., \& Tulai, O. (2020). Determinant effects of political and economic factors on country risk: An evidence from the EU countries. Montenegrin Journal of Economics, 16(1), 3753. https://doi.org/10.14254/1800-5845/2020.16-1.3 
Hammer, Ø., Harper, D., \& Ryan, P. (2001). PAST: Paleontological statistics software package for education and data analysis. Palaeontologia Electronica, 4(1), 9. https://palaeoelectronica.org/2001_1/past/past.pdf

Hanák, R. (2016). Dátová analýza pre sociálne vedy. Vydavatel'stvo EKONÓM. https://statistikapspp.sk/ucebnica/datova-analyza-pre-socialne-vedy/

Hassan, T. A., Hollander, S., van Lent, L., \& Tahoun, A. (2019). Firm-level political risk: Measurement and effects. The Quarterly Journal of Economics, 134(4), 2135-2202. https://doi.org/10.1093/qje/qjz021

Hayes, N. L. (1998). Country risk revisited. Journal of Lending and Credit Risk Management, 80(5), 61.

Hoti, S., \& McAleer, M. (2004). An empirical assessment of country risk ratings and associated models. Journal of Economic Surveys, 18(4), 539-588. https://doi.org/10.1111/j.09500804.2004.00230.x

Iloie, R. E. (2015). Connections between FDI, Corruption Index and Country Risk Assessments in Central and Eastern Europe. Procedia Economics and Finance, 32, 626-633. https://doi.org/10.1016/S2212-5671(15)01442-2

Khadduri, M. (1953). The role of the military in Middle East politics. American Political Science Review, 47(2), 511-524. https://doi.org/10.2307/1952036

Kittová, Z., \& Steinhauser, D. (2017). Institutional and macroeconomic environment of corporations. Politická Ekonomie, 65(2), 234-248. https://doi.org/10.18267/j.polek.1138

Lukáčik, M., Lukáčiková, A., \& Szomolányi, K. (2011). Ekonometrické modelovanie v programoch EViews a Gretl. Vydavatel'stvo EKONÓM.

Marquez, A. (1990). The other path by Hernando De Soto. Boston College Third World Law Journal, 10(1), 204-213. https://lawdigitalcommons.bc.edu/twlj/vol10/iss1/9/

Michník, L'. (1995). The role of specialised institutions in the Business Information-System. Ekonomický Časopis (Journal of Economics), 43(1), 64-75.

Mlčoch, L. (2005). Institucionální ekonomie (2nd. ed.). Nakladatelství Karolinum.

Muir, T. (2017). Financial crises and risk premia. The Quarterly Journal of Economics, 132(2), 765-809. https://doi.org/10.1093/qje/qjw045

Munger, M. C. (2018). Tullock and the welfare costs of corruption: There is a 'political Coase Theorem'. Public Choice, 181(1-2), 83-100. https://doi.org/https://doi.org/10.1007/s11127-018-0610-9

North, D. C. (1971). Institutional change and economic growth. Journal of Economic History, 31(1), 118125. https://doi.org/10.1017/S0022050700094109

North, D. C., \& Thomas, R. P. (1973). The rise of the western world. Cambridge University Press.

Overholt, W. H. (1982). Political Risk. Euromoney Publications.

Pacáková, V., Labudová, V., Sipková, L., Šoltés, E., \& Vojtková, M. (2009). Štatistické metódy pre ekonómov. lura Edition.

Rabi, U., \& Ter-Oganov, N. (2012). The military of Qajar Iran: The features of an irregular army from the eighteenth to the early twentieth century. Iranian Studies, 45(3), 333-354, https://doi.org/10.1080/00210862.2011.637776 
Ramcharran, H. (1999). The determinants of secondary market prices for developing country loans: The impact of country risk. Global Finance Journal, 10(2), 173-186. https://doi.org/10.1016/S10440283(99)00011-3

Swaminathan, A., \& Wade, J. B. (2016). Institutional environment. In M. Augier \& D. J. Teece (Eds.), The Palgrave encyclopedia of strategic management (pp. 1-7). Palgrave Macmillan UK. https://doi.org/10.1057/978-1-349-94848-2_608-1

The Heritage Foundation. (2020). 2020 Index of Economic Freedom. https://www.heritage.org/index/excel/2020/index2020_data.xls

The Heritage Foundation. (2021a). About the Index. https://www.heritage.org/index/about

The Heritage Foundation. (2021b). Key findings of the 2021 Index.

https://www.heritage.org/index/pdf/2021/book/2021_IndexofEconomicFreedom_CHAPTER01.p $\mathrm{df}$

The Heritage Foundation. (2021c). Czech Republic.

https://www.heritage.org/index/country/czechrepublic

The Heritage Foundation. (2021d). Hungary. https://www.heritage.org/index/country/hungary

The Heritage Foundation. (2021e). Poland. https://www.heritage.org/index/country/poland

The Heritage Foundation. (2021f). Poland. https://www.heritage.org/index/country/slovakia

Williamson, O. E. (1990). Die ökonomischen Institutionen des Kapitalismus: Unternehmen, Märkte, Kooperationen (translation M. Streissler). Mohr Siebeck.

Zykiene, I., Snieska, V., Bruneckiene, J., \& Burksaitiene, D. (2020). Assessment of regions using an index for a location's attractiveness for business development. Economic Research-Ekonomska Istraživanja, 1-19. https://doi.org/10.1080/1331677X.2020.1825106

The research article passed the review process. | Received: February 4, 2021; Revised: June 7, 2021; Accepted: June 25, 2021; Pre-published online: October 31, 2021; Published in the regular issue: May 19, 2022. 